\title{
Intraventricular Pleomorphic Xanthoastrocytoma: A Case Report
}

\section{Intraventriküler Pleomorfik Ksantoastrositom: Bir Olgu Sunumu}

\author{
Ricardo MENÉNDEZ ${ }^{1}$, Julio FERNÁNDEZ ${ }^{1}$, Alfredo MONTI ${ }^{1}$, Gustavo SEVLEVER ${ }^{2}$ \\ ${ }^{1}$ Hospital Bernardo Houssay, Division of Neurosurgery, Vicente Lopez, Argentina \\ ${ }^{2}$ Institute for Neurological Research "Raul Carrea", FLENI, Department of Neuropathology, Buenos Aires, Argentina
}

Corresponding Author: Ricardo MENÉNDEZ / E-mail: rhmenendez@hotmail.com

\begin{abstract}
Pleomorphic xanthoastrocytoma (PXA), an uncommon glial neoplasm, typically affects adolescents and young adults and accounts for less than $1 \%$ of all astrocytic neoplasms. The authors present a case of PXA located entirely in the third ventricle in a 24-year-old male patient. The patient presented with a 6-month history of headaches, progressive decline in cognitive function and profound behavioral disturbances. He was admitted to the hospital with signs of increased intracranial pressure. Magnetic resonance imaging showed a well-enhanced solid tumor, located entirely inside the third ventricle. The tumor was totally removed via a right fronto-pterional trans-lamina terminalis approach and neuropathology report confirmed PXA diagnosis. No further treatment was indicated. To the best of our knowledge, this is the first case report of a solid PXA confined to the third ventricle.
\end{abstract}

KEYWORDS: Pleomorphic xanthoastrocytoma, Intraventricular, Immuno-histochemical

öz

Pleomorfik ksantoastrositom (PXA) nadir bir gliyal neoplazidir ve tipik olarak adolesanlar ve genç yetişkinlerde görülüp, tüm astrositik neoplazmların \%1'inden azını oluşturur. Yazarlar 24 yaşında bir erkek hastada tamamen üçüncü ventrikülde bulunan PXA olgusu sunmaktadır. Hasta 6 aylık başağrısı, bilişsel işlevde giderek azalma ve belirgin davranış bozuklukları öyküsüyle geldi. Artmış intrakraniyal basınç bulgularıyla hastaneye yatırıldı. Manyetik rezonans görüntüleme tamamen üçüncü ventrikül içinde bulunan ve iyi kontrast tutan bir solid tümör gösterdi. Tümör sağ fronto-pterional trans-lamina terminalis yaklaşımı ile tamamen çıkarıldı ve nöropatoloji raporu PXA tanısını doğruladı. Başka bir tedavi gerekmedi. Bildiğimiz kadarıyla bu üçüncü ventrikülle sınırlı solid bir PXA için ilk olgu raporudur.

ANAHTAR SÖZCÜKLER: Pleomorfik ksantoastrositom, İntraventriküler, İmmünohistokimyasal

\section{INTRODUCTION}

Since its original description by Kepes and coauthors in 1979 (20), pleomorphic xanthoastrocytoma (PXA) has been regarded as a distinct astrocytic tumor, with more favorable prognosis than infiltrating astrocytomas (21). PXAs are typically located in the cerebral hemispheres, particularly the temporal lobe, often in close contact to leptomeninges. Approximately half the tumors present a cystic component $(3,7,10)$. Due to the lesion's superficial location involving the cerebral cortex, seizures are the most common mode of presentation (3). Examples of this unusual neoplasm have also been reported in the cerebellum $(11,12,14,23,31,35)$, pineal region (27), sella turcica (2), spinal cord $(15,26)$, and even the retina (40). PXA often arises in adolescents and young adults and is amenable to surgical resection with good disease control(8), although it may harbor the potential for malignant transformation $(1,4,5,6,9,25,28,30,32,38)$. To our knowledge, this is the first reported case of a solid PXA located exclusively within the third ventricle, a site not previously described in the literature. We discuss the clinical course, management and pathology findings.

\section{CASE REPORT}

A 24-year-old male patient, with a unremarkable medical history, was admitted with a 6-month history of progressive headache, hypersomnia and behavioral changes, including apathy and aggression. During this period, the patient underwent a change in eating habits, referring hyperphagia and weight gain of over $20 \mathrm{kgs}$. During the days prior to admission, symptoms had gradually worsened and he had experienced episodes of confusion as well as nausea and vomiting. On initial physical examination, the patient appeared obese and lethargic, with evident impairment of spontaneous higher cognitive activities. Ophthalmologic examination disclosed bilateral papilledema and subnormal visual acuity. Preoperative hormone lab tests were unremarkable.

Computed tomographic (CT) imaging showed a spontaneously hyperdense rounded mass, in the third ventricle region (Figure 1A). Magnetic Resonance Imaging (MRI) scan revealed a well-enhanced solid tumor, entirely confined to the third ventricle measuring $35 \mathrm{~mm}$ in diameter, causing anterior displacement of the optic chiasm. Edema of both hippocampal 
regions and cerebral peduncles was also observed. There was no associated hydrocephalus. No evidence of calcification or cystic components was found (Figure 1B-D).

Based on clinical presentation and imaging findings, differential diagnoses considered were intraventricular craniopharyngioma or chiasmal/hypothalamic glioma.

Excision was performed via a right fronto-pterional approach. After incision of the distended lamina terminalis, the underlying tumor mass was visualized. A firm grayish-yellow mass, the tumor was progressively debulked and separated from the chiasm, the third ventricle walls and the pituitary stem, and successfully resected in its entirety.

Histological sections showed an hypercellular neoplasia. Tumor cells were pleomorphic with abundant pink cytoplasm arranged in fascicles or storiform pattern. Numerous cells disclosed foamy, lipid-filled cytoplasm, intermixed with others with bizarre nuclei, occasionally multinucleated (Figure 2A, B). Some lymphocytes were also detected in a perivascular distribution. Mitotic figures were scarce. No necrosis was observed.

Some cells displayed morphologic and immunocytochemical features of neuronal differentiation. Glial fibrillary acidic protein (GFAP) decorated some of the pleomorphic neoplasic astrocytes while neurofilament disclosed immunopositivity in others (Fig 2C, D). Kinetic activity (MIB 1 immunostaining) was low (Figure 2E). The histological results were consistent with a pleomorphic xanthoastrocytoma.

Post-operative MRI scan confirmed a complete excision (Figure $3 \mathrm{~A}-\mathrm{C}$ ). During the immediate postoperative period, patient developed transient diabetes insipidus requiring desmopressin, subsequently tapered until discontinuation. Discharge occurred 20 days after surgery. Patient progressively resumed daily life activities, with slow improvement of cognitive and visual impairment, though requiring permanent hormone replacement therapy with levothyroxine and hydrocortisone. Surgery was the only treatment. Regular MRI follow-up performed at 6,12 and 48 months showed no evidence of tumor relapse.

\section{DISCUSSION}

PXAs were added to the 1993 World Health Organization (WHO) classification of central nervous system tumors as a separate diagnosis, corresponding histologically to Grade II tumors (21). Authors of the original study, as well as others, have suggested the subpial astrocyte as the cell of origin (13).
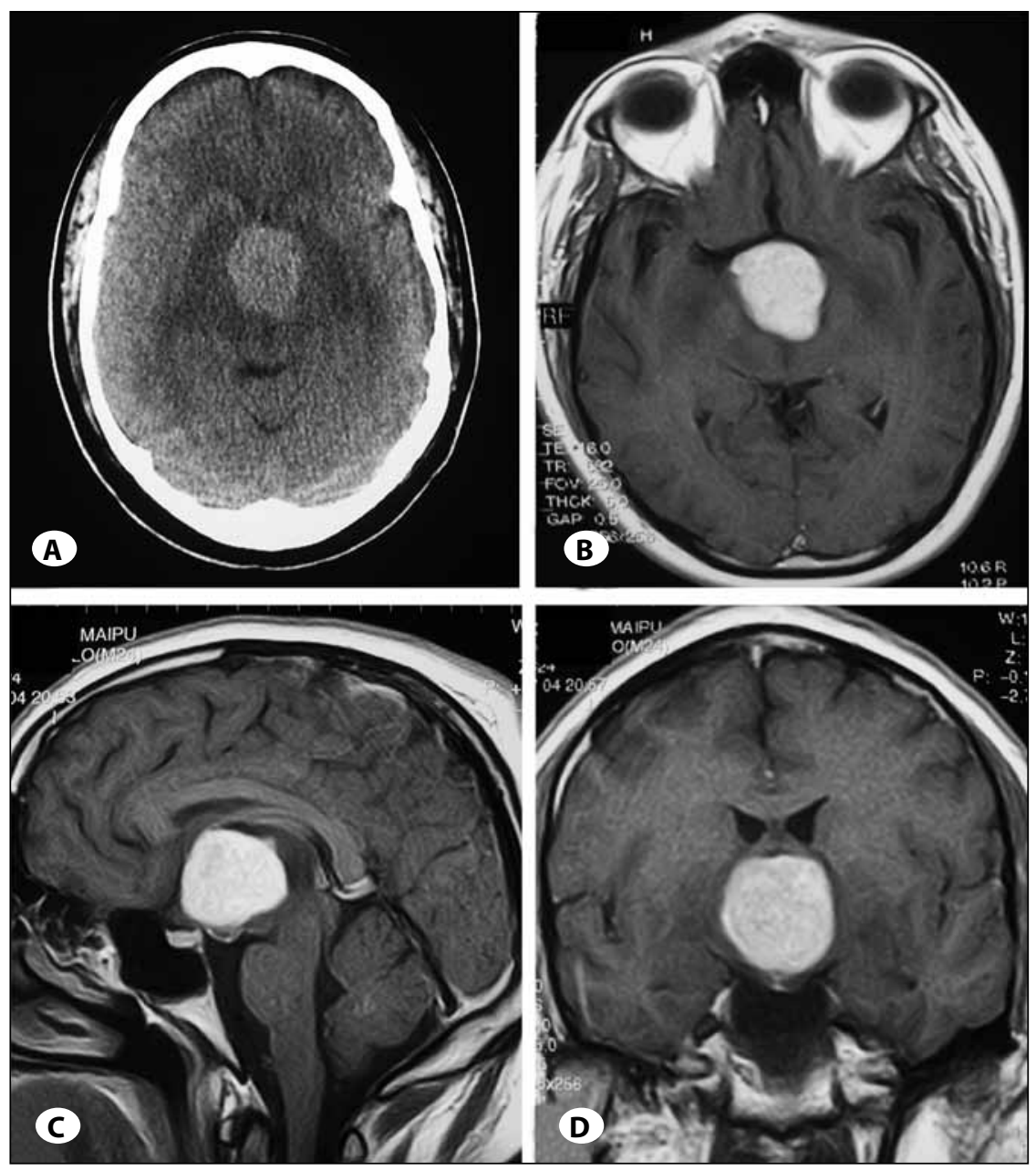

Figure 1: A) Preoperative CT scan showing spontaneously hyperdense solid lesion in third ventricle with no associated hydrocephalus. B) Axial, C) sagittal and D) coronal T1-weighted contrast-enhanced MRI scans revealing a large solid tumor situated entirely within the third ventricle cavity, homogeneously enhanced with gadolinium-DTPA. 
Before immunohistochemistry techniques were developed, most PXAs were classified as mesenchimal neoplasms such as xanthomas or xanthosarcomas, due to the abundant reticulin network often found in these tumors, and the resemblance of its lipidized neoplastic glial cells to foamy histiocytes (18). The superficial location and intense desmoplastic reaction causing adherence to adjacent dura, contributed to the confusion concerning the origin of this neoplasm. GFAP reactivity is usually present on immunostaining. In contrast to mesenchimal tumors and giant cell glioblastomas, PXAs are associated with an intermediate prognosis. Malignant progression of PXAs, although rare, has been documented, with mitotic index and extent of resection as main predictors of outcome $(10,16,19,24,36,37)$.

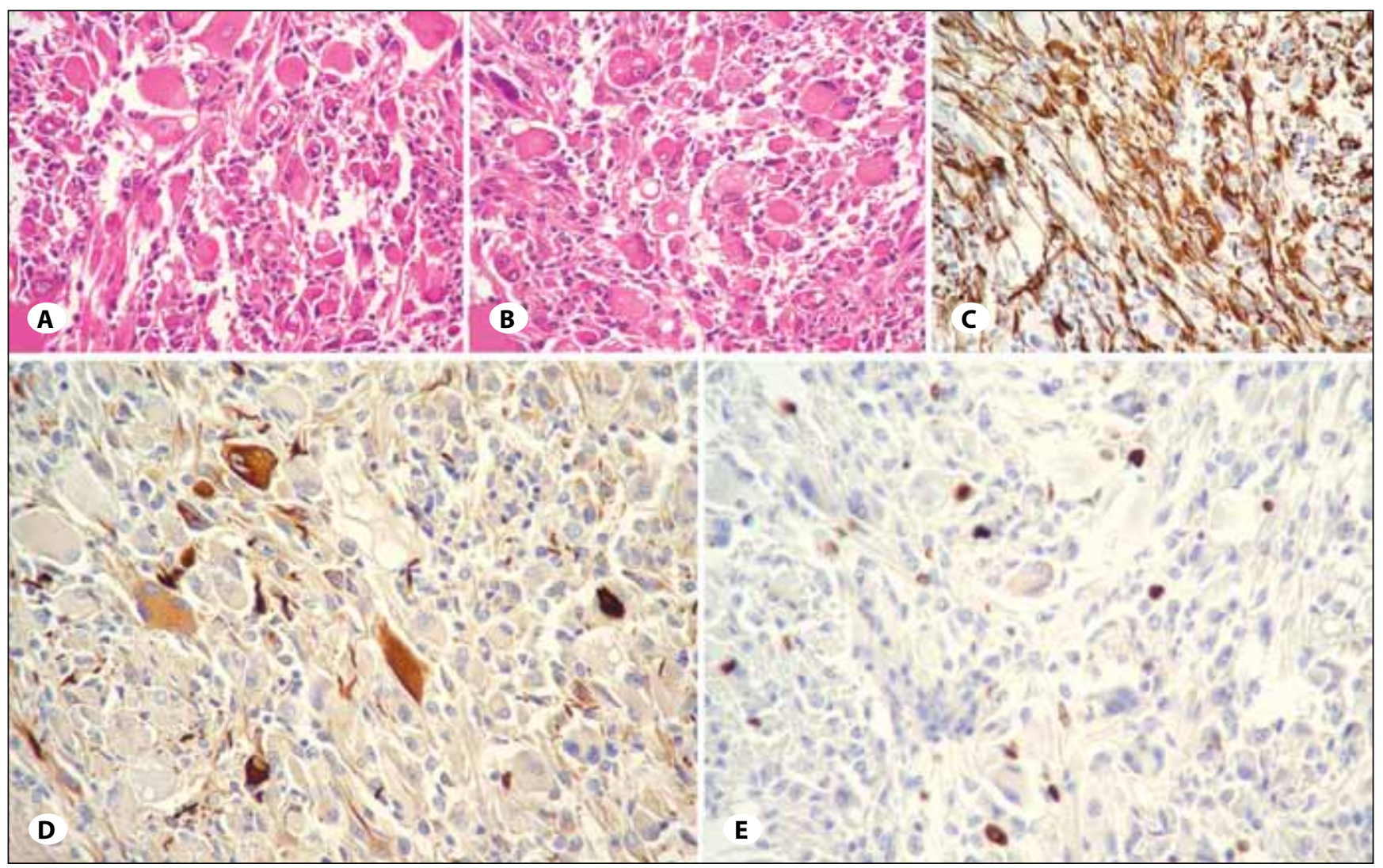

Figure 2: Photomicrographs showing the tumor's histopathological features. A) Pleomorphic cells with xantomized cytoplasm. B) Multinucleated giant-cells with intracytoplasmic vacuoles. C) Positive immunostaining with GFAP. D) Pleomorphic cells immunoreactive for Neurofilament. E) Some cells immunopositive for Ki 67. H \& E: (A and B), GFAP: (C), NF: (D), and Ki 67 (E). Original magnification $\times 400$.
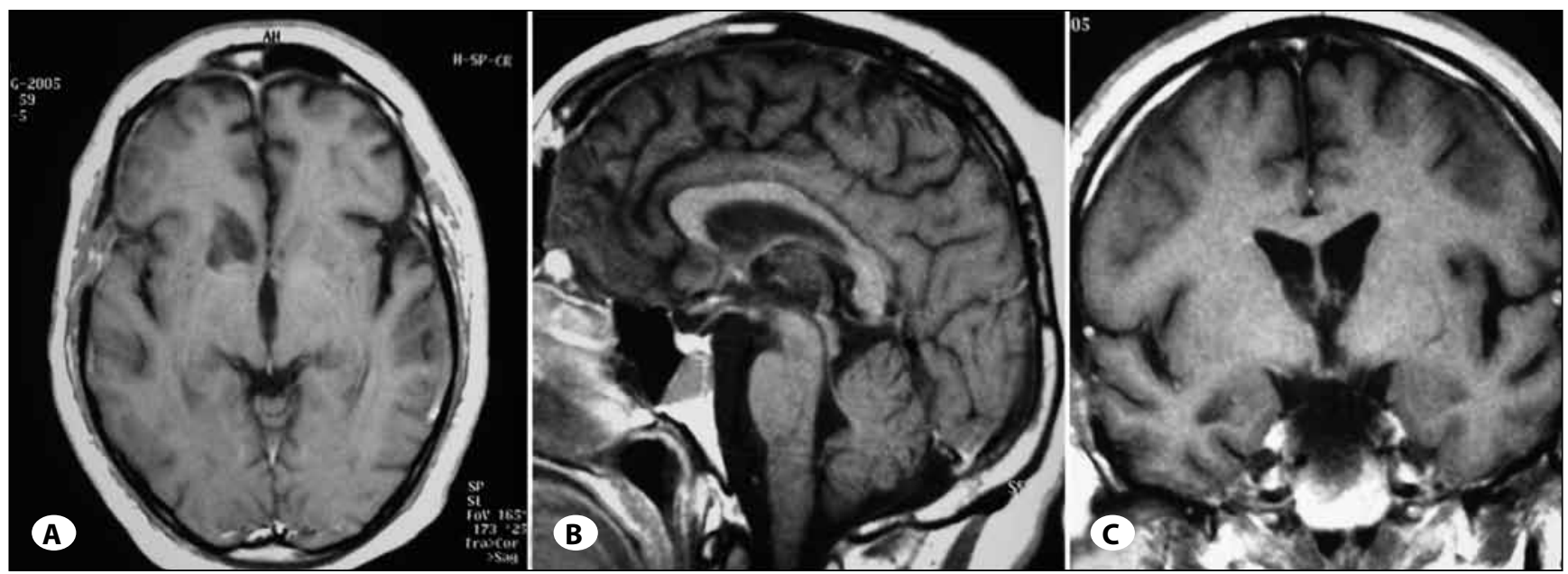

Figure 3: Postoperative A) axial, B) sagittal and C) coronal MRI scans confirming total removal of the tumor. 
PXA typically presents as a well-demarcated solid-cystic mass involving the superficial temporal lobe, with intense contrast enhancement of the solid portion of tumor in most imaging modalities $(13,39)$. Entirely solid masses, as in this case, are highly unusual.

Presence of these tumors within the third ventricle is extremely rare and we found no published reports of any previous case in this location in the medical literature.

Although the primary goal of surgical treatment of PXA is complete resection $(8,10,17,20,29)$, subtotal resections have been associated with good long-term outcome (24). There appears to be no benefit to adjunctive radiation therapy (34). Postoperative radiotherapy is reserved for patients with anaplastic and recurrent tumors with malignant changes $(4,5$, $22,33)$. Chemotherapy has not been adequately studied (30).

Treatment objective is always through tumor removal, with preservation of neural and vascular anatomical integrity of the affected brain region, regarded as critically significant to postoperative outcome.

\section{CONCLUSIONS}

PXA is an astrocytic tumor with a relatively favorable prognosis overall. We describe a unique case of solid PXA wholly situated within the third ventricle. Definitive PXA diagnosis rests on accurate interpretation of pathological findings. It is important to recognize factors that might be associated with a less benign clinical course such as mitotic index and necrosis. In the absence of further extensive literature on the natural history of these tumors, the first treatment approach to be attempted whenever possible is radical surgical resection with prolonged postoperative clinical and radiological follow up.

Third ventricle location may prove challenging for complete resection. If the tumor is closely adhered to the third ventricle wall and complete removal implies high risk of hypothalamus damage, subtotal removal is advisable, followed by close post-operative follow up. Adjuvant therapy is required only if tumor re-growth occurs.

\section{REFERENCES}

1. Allegranza A, Ferraresi $S$, Bruzzone $M$, Giombini S: Cerebromeningeal pleomorphic xanthoastrocytoma. Report on four cases: Clinical, radiologic and pathological features (Including a case with malignant evolution). Neurosurg Rev 14:43-49, 1991

2. Arita K, Kurisu K, Tominaga A, Sugiyama K, Sumida M, Hirose $\mathrm{T}$ : Intrasellar pleomorphic xanthoastrocytoma: Case report. Neurosurgery 51:1079-1082, 2002

3. Blom RJ: Pleomorphic xanthoastrocytoma: CT appearance. J Comput Assist Tomogr 12:351-352, 1988

4. Chakrabarty A, Mitchell P, Bridges LR, Franks AJ: Malignant transformation in pleomorphic xanthoastrocytoma-A report of two cases. Br J Neurosurg 13:516-519, 1999
5. Charbel FT: Pleomorphic xanthoastrocytoma with malignant progression. Surg Neurol 50:385-386, 1998

6. De Tella OI Jr, Herculano MA, Prandini MN, Stavale JN, Aguiar $\mathrm{PH}$ : Malignant transformation of pleomorphic xanthoastrocytoma: Case report. Arq Neuropsiquiatr 61:104-106, 2003

7. Farmer JP, McNeely PD: Pleomorphic Xanthoastrocytoma. In: Tonn JC, Westphal M, Rutka JT, Grossman SA (eds), Neurooncology of CNS Tumors. Berlin, Heidelberg, New York: Springer, 2006:436-441

8. Fouladi $M$, Jenkins J, Burger $P$, Langston J, Merchant $T$, Heideman R, Thompson S, Sanford A, Kun L, Gajjar A: Pleomorphic xanthoastrocytoma: Favorable outcome after complete surgical resection. Neuro-Oncol 3:184-192, 2001

9. Fu YJ, Miyahara $H$, Uzuka T, Natsumeda $M$, Okamoto $K$, Hirose T, Fujii Y, Takahashi H: Intraventricular pleomorphic xanthoastrocytoma with anaplastic features. Neuropathology 30(4):443-448, 2009

10. Giannini C, Scheithauer BW, Burger PC, Brat DJ, Wollan PC, Lach B, O'Neill BP: Pleomorphic xanthoastrocytoma: What do we really know about it? Cancer 85:2033-2045, 1999

11. Gil-Gouveia R, Cristino N, Farias JP, Trindade A, Ruivo NS, Pimentel J: Pleomorphic xanthoastrocytoma of the cerebellum: Illustrated review. Acta Neurochir (Wien) 146:1241-1244, 2004

12. Glasser RS, Rojiani AM, Mickle JP, Eskin TA: Delayed occurrence of cerebellar pleomorphic xanthoastrocytoma after supratentorial pleomorphic xanthoastrocytoma removal. Case report. J Neurosurg 82:116-118, 1995

13. Gokaslan Z, Tihan T: Pleomorphic Xanthoastrocytoma. In: Berger MS, Prados MD (eds), Textbook of Neuro-Oncology. Philadelphia: Elsevier Saunders, 2005:649-651

14. Hamlat A, Le Strat A, Guegan Y, Ben-Hassel M, Saikali S: Cerebellar pleomorphic xanthoastrocytoma: Case report and literature review. Surg Neurol 68:89-94; discussion 94-95, 2007

15. Herpers MJ, Freling G, Beuls EA: Pleomorphic xanthoastrocytoma in the spinal cord. Case report. J Neurosurg 80: 564-569, 1994

16. Iwaki T, Fukui M, Kondo A, Matsushima T, Takeshita I: Epithelial properties of pleomorphic xanthoastrocytomas determined in ultraestructural and immunohistochemical studies. Acta Neuropathol 74:142-150, 1987

17. Kepes JJ: Pleomorphic xanthoastrocytoma: The birth of a diagnosis and a concept. Brain Pathol 3:269-274, 1993

18. Kepes JJ, Kepes M, Slowik F: Fibrous xanthomas and xanthosarcomas of the meninges and the brain. Acta Neuropathol 23:187-199, 1973

19. Kepes JJ, Rubinstein LJ, Ansbacher L, Schreiber DJ: Histopathological features of recurrent pleomorphic xanthoastrocytomas: Further corroboration of the glial nature of this neoplasm. A study of 3 cases. Acta neuropathol 78:585-593, 1989

20. Kepes JJ, Rubinstein LJ, Eng LF: Pleomorphic xanthoastrocytoma: A distinctive meningocerebral glioma of young subjects with relatively favorable prognosis- A study of 12 cases. Cancer 44:1839-1852, 1979 
21. Kleihues P, Burger PC, Scheithauer BW (eds), Histological typing of tumours of the central nervous system. World Health Organization, 2nd ed. New York: Springer, 1993

22. Leonard N, Alcutt DA, Farrell MA: Fatal pleomorphic xanthoastrocytoma with meningeal gliomatosis. Histopathology 32:375-378, 1998

23. Lim SC, Jang SJ, Kim YS: Cerebellar pleomorphic xanthoastrocytoma in an infant. Pathol Int 49:811-815, 1999

24. Macaulay RJ, Jay V, Hoffman HJ, Becker LE: Increased mitotic activity as a negative prognostic indicator in pleomorphic xanthoastrocytoma. Case report. J Neurosurg 79:761-768, 1993

25. Marton E, Feletti A, Orvieto E, Longatti P: Malignant progression in pleomorphic xanthoastrocytoma: Personal experience and review of the literature. J Neurol Sci 253: 144-153, 2007

26. Nakamura M, Chiba K, Matsumoto M, Ikeda E, Toyama Y: Pleomorphic xanthoastrocytoma of the spinal cord. Case report. J Neurosurg Spine 5:72-75, 2006

27. Nitta J, Tada T, Kyoshima K, Goto T, Ishii K, Hongo K, Kobayashi S: Atypical pleomorphic astrocytoma in the pineal gland: Case report. Neurosurgery 49:1458-1460, 2001

28. Okazaki T, Kageji T, Matsuzaki $K$, Horiguchi $H$, Hirose $T$, Watanabe H, Ohnishi T, Nagahiro S: Primary anaplastic pleomorphic xanthoastrocytoma with widespread neuroaxis dissemination at diagnosis-a pediatric case report and review of the literature. J Neurooncol 94(3):431-437, 2009

29. Pahapill PA, Ramsay DA, Del Maestro RF: Pleomorphic xanthoastrocytoma: Case report and analysis of the literature concerning the efficacy of resection and the significance of necrosis. Neurosurgery 38:822-828; discussion 828-829, 1996

30. Rao G, Kestle JRW: Pleomorphic Xanthoastrocytoma. In Berger MS, Prados MD (eds), Textbook of Neuro-Oncology. Philadelphia: Elsevier Saunders, 2005:649-651
31. Rosemberg S, Rotta JM, Yassuda A, Velasco O, Leite CC: Pleomorphic xanthoastroytoma of the cerebellum. Clin Neuropathol 19:238-242, 2000

32. Tekkok IH, Sav A: Anaplastic pleomorphic xanthoastrocytomas. Review of the literature with reference to malignancy potencial. Pediatr Neurosurg 40:171-181, 2004

33. Tonn JC, Paulus W, Warmuth-Metz M, Schachenmayr, Sörensen N, Roosen K: Pleomorphic xanthoastrocytoma: Report of six cases with special consideration of diagnostic and therapeutic pitfalls. Surg Neurol 47:162-169, 1997

34. Van Roost D, Kristof R, Zentner J, Wolf HK, Schramm J: Clinical, radiological, and therapeutic features of pleomorphic xanthoastrocytoma: Report of three patients and review of the literature. J Neurol Neurosurg Psychiatry 60:690-692, 1996

35. Wasdahl DA, Scheithauer BW, Andrews BT, Jeffrey RA Jr: Cerebellar pleomorphic xanthoastrocytoma: Case report. Neurosurgery 35:947-950; discussion 950-951, 1994

36. Weldon-Linne CM, Victor TA, Groothuis DR, Vick NA: Pleomorphic xanthoastrocytoma. Ultrastructural and immunohistochemical study of a case with a rapidly fatal outcome following surgery. Cancer 52:2055-2063, 1983

37. Whittle IR, Gordon A, Misra BK, Shaw JF, Steers AJ: Pleomorphic xanthoastrocytoma. Report of four cases. J Neurosurg 70:463-468, 1989

38. Yang $W Q$, Huang $B$, Liang $\mathrm{CH}$ : Pleomorphic xanthoastrocytoma in the lateral ventricle with extensive subarachnoid dissemination: Report of a case and review of the literature. Chin Med J (Engl)125(2):396-399, 2012

39. Yoshino MT, Lucio R: Pleomorphic xanthoastrocytoma. AJNR Am J Neuroradiol 13:1330-1332, 1992

40. Zarate JO, Sampaolesi R: Pleomorphic xanthoastrocytoma of the retina. Am J SurgPathol 23:79-81,1999 